\title{
صيغة أفعل في سورة البقرة ودلالتها: دراسة وصفية تحليلية
}

\author{
Hasyim Ashari \\ Sekolah Tinggi Agama Islam Negeri (STAIN) Majene \\ Email:hasyim.azhary87@gmail.com
}

(Submitted: 10-02-2020, Accepted: 19-05-2020)

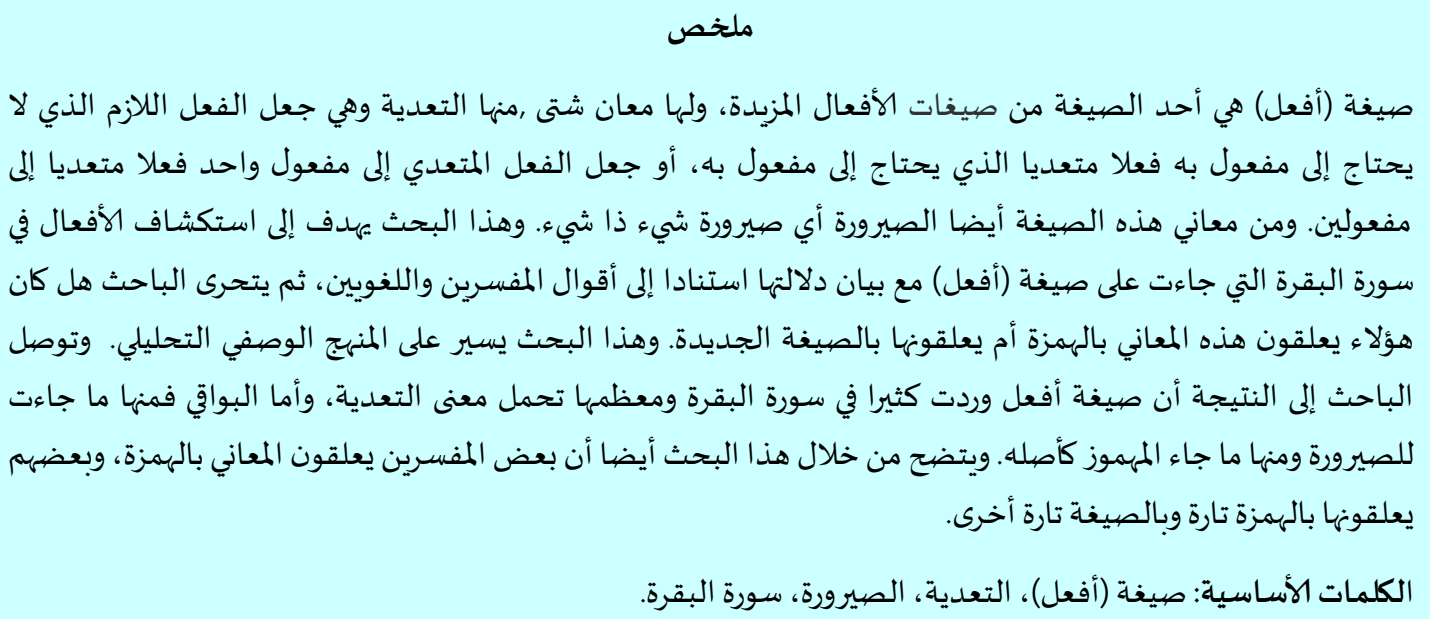

\section{Abstrak}

Kata kerja dengan timbangan af'ala merupakan salah satu bentuk kata kerja di dalam bahasa Arab yang mendapatkan huruf tambahan, dan memiliki beragam makna di antaranya al-ta'diyyah yaitu merubah kata kerja dari yang tidak membutuhkan objek menjadi kata kerja yang membutuhkan objek, atau dari yang membutuhkan satu objek menjadi kata kerja yang membutuhkan dua objek. Makna lain dari kata kerja dengan timbangan af'ala adalah al-sayrurah yaitu menjadikan sesuatu memiliki hal baru. Dan tulisan ini bertujuan untuk mendeteksi adanya kata kerja dengan timbangan af'ala di dalam surah al-Baqarah dengan menjelaskan maknanya berdasarkan pendapat para ahli tafsir dan bahasa, dan selanjutnya mendeteksi apakah para ahli tafsir menganggap bahwa maknamakna tersebut dibawa oleh huruf hamzah, atau berasal dari bentuk kata baru. Adapun metode yang digunakan adalah pendekatan deskriptif analisis. Dan penulis menemukan bahwa sangat banyak kata kerja di dalam surah al-Baqarah dengan timbangan af'ala, dan mayoritas mengandung makna al-ta'diyyah, sedangkan selebihnya bermakna al-sayrurah, dan ada pula yang maknanya tetap sama sebelum kata kerja tersebut mendapatkan tambahan hamzah.Dan ditemukan juga bahwa sebagian ahli tafsir menganggap makna-makna tersebut dibawa oleh huruf hamzah, dan sebagian lagi terkadang menganggap huruf hamzah dan terkadang menganggap bentuk baru dari kata yang membawa makna-makna tersebut.

Kata kunci: Timbangan Af'ala, al-Ta'diyyah, al-Sayrurah, Surah al-Baqarah

Pengutipan: Ashari, Hasyim. "صيغة أفعل في سورة البقرة ودلالها: دراسة وصفية تحليلية Diwan, vol. 6 no. 1 (Juni 2020). https://doi.org/10.24252/diwan.v6i1.12496 
إن زيادة الحرف أو الأحرف في الكلمة لم تكن مجرد زيادة عدد أحرفها فحسب، فالزيادة

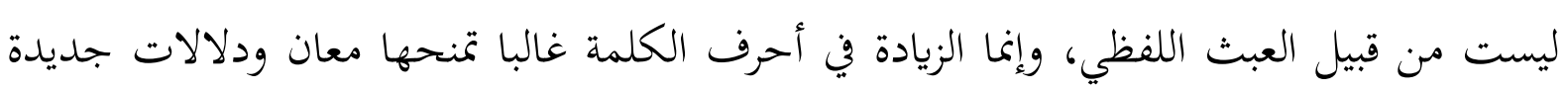

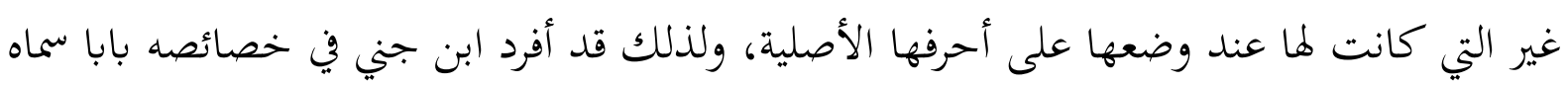

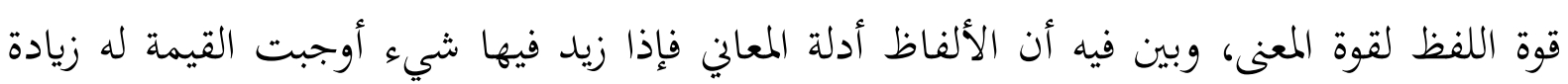
المعنى به. فحرى أن نعرف اشتقاقات كل كلمة وتصريفاتما وما طرأ عليه من التغيرات في المعنى وخاصة

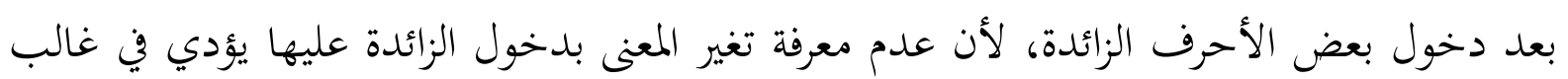
الأحيان إلى صعوبة فهم النصوص وإن لم يكن مستحيلا. ومن المعروف أن الكلمة في اللغة العربية تنقسم إلى ثلاثة أقسام وهي : اسم وفعل وحرف، إنه

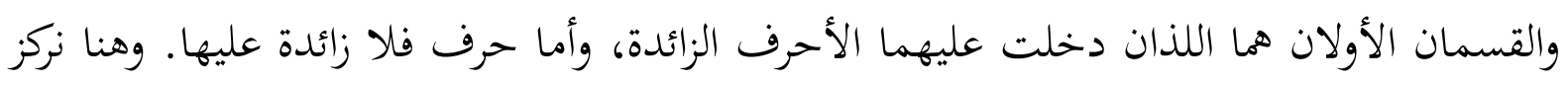
اهتمامنا في الفعل فقط. فمعظم الفعل أصله ثلاثي و ولكنه قابل للزيادة سواء كانت الزيادة بحرف

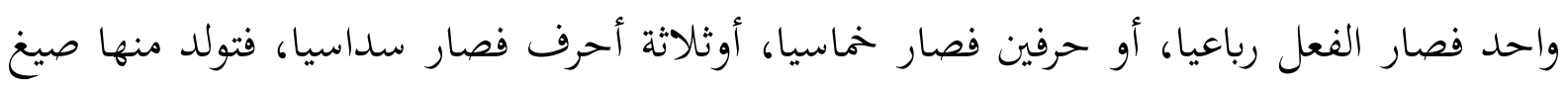
جديدة ودلالات متنوعة. ولكي يكون هذا الموضوع واضحا جليا فسندرسه من خلال الكال الآيات القرآنية، وذلك لكثرة ورود الأفعال في القرآن الكريم وبالتحديد المزيدة منها. وهنا سيحاول الباحث البحث عن أحد الصيغ المزيدة وهي صيغة (أفعل) ووروده في سورة البقرة. فإذا قرأنا هذه السورة وأمعنا النظر فيها فسنعرف أها مليئة بأفعال جاءت آبحت على صيغة (أفعل) بمعانيها المختلفة.

ووجد الباحث بعض المباحثات والمقالات المتعلقة بهذا البحث، وأقرها شبها الرسالة في

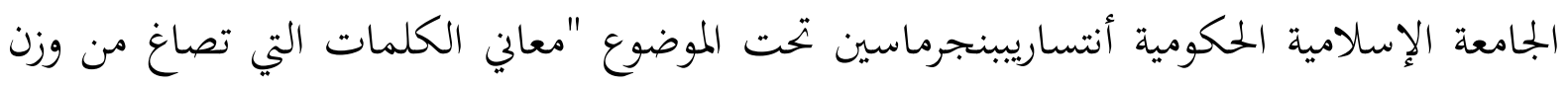

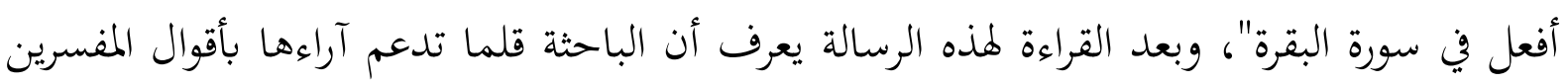

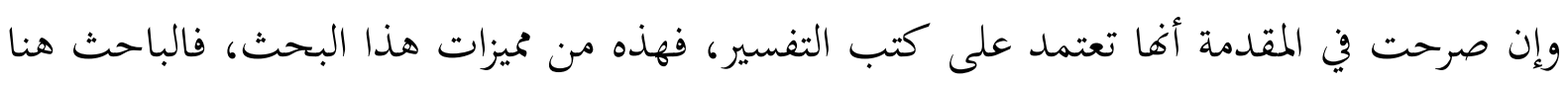

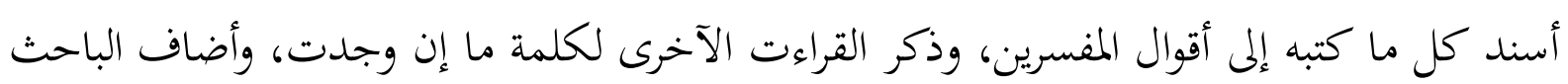

$$
\text { أبو الفنح عثمان بن جني، الخصائص، (بيروت: عالم الكتب، } 1427 \text { م)، ص. } 813 .
$$


فيه القول عن تعليق معاني صيغة أفعل. ومما ذكرنا سابقا يمكن أن نحدد مشكلة البحث من خلال التساؤلات الآتية : nis

1 - هل وجدت الأفعال بصيغة (أفعل) في سورة البقرة؟

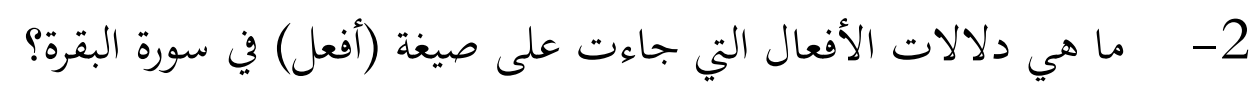

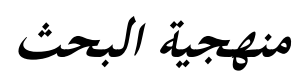

يسير هذا البحث على المنهج الوصفي التحليلي، حيث يقوم الباحث أولا بجمع المواد العلمية المتعلقة

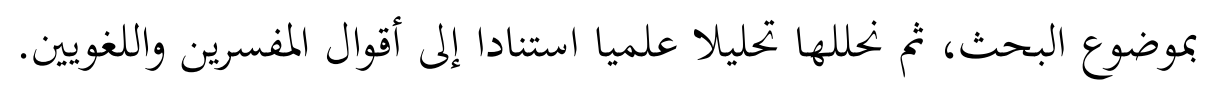
أما بالنسبة لمنهج جمع المواد فنعتمد على المصدر الرئيسي وهو القرآن الكريم لأن بحثنا يكون في

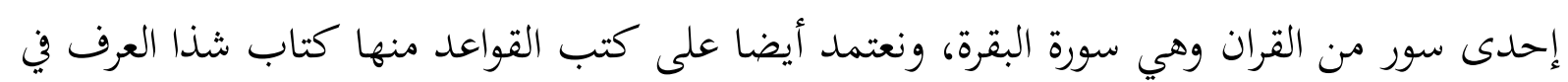
فن الصرف للشيخ الحملاوي، وكذلك بعض كتب شروح ألفية ابن مالك لأن بكثنا يتعلق بعلم الصرف. ولتأييد ما حصلنا من النتائج فندعمها بأقوال المفسيرين في تفاسيرهم مثل التفسير الكبير

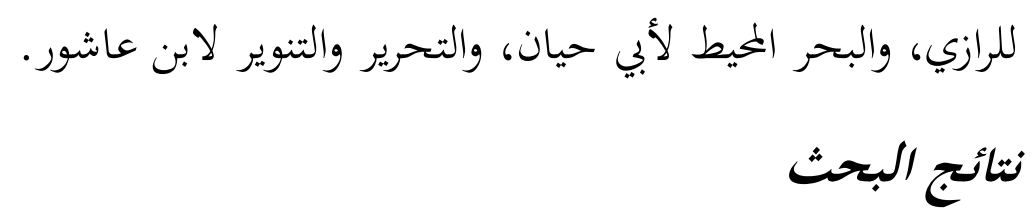
تقسيم الفعل إلى الجرد والمزيد

ينقسم الفعل بحسب التجرد والزيادة إلى الفعل المجرد والفعل المزيد، فإذا كان جميع حروفه

أصلية لا زيادة فيها فنسميه بجردا. أما الذي زيد فيه حرف أو أكثر على حروفه الأصلية فهو مزيد النيد.

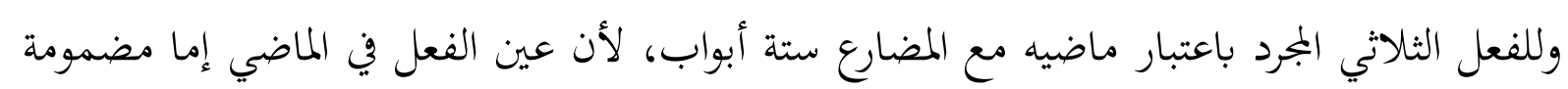

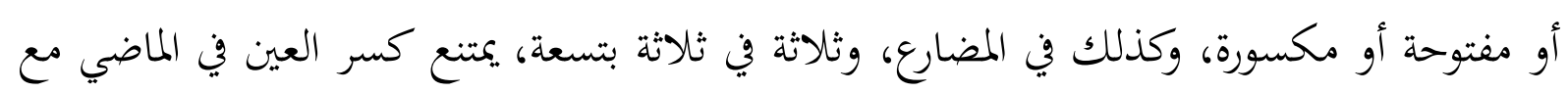

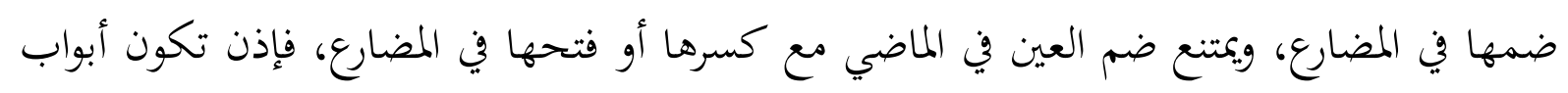
الثلاثي ستة وهي: - n

الباب الأول: فعَل - يفعُل (بفتح العين في الماضي وضمها في المضارع) نحو: نصرَ -ينصُر،

$$
\text { وقال - يقُول، ومدّد- يُمدّد }
$$




\section{Hasyim Ashari}

صيغة أفعل في سورة البقرة ودلالتها: دراسة وصفية تحليلية

الباب الثاني: فعَل - يفعِل (بفتح العين في الماضي وكسرها في المضارع) نحو: ضرَب- يضرِب،

$$
\text { وباع- يبيع، وفرّ - ينِرّ }
$$

الباب الثالث: فعَل - يفعَل (بفتح العين في الماضي والمضارع) نحو: فتَح- يفتَح، ووضَعَ-

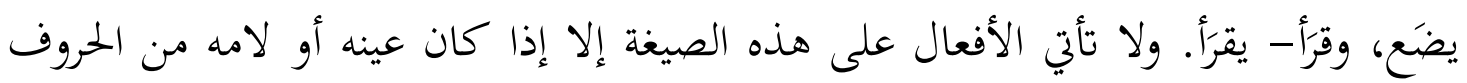

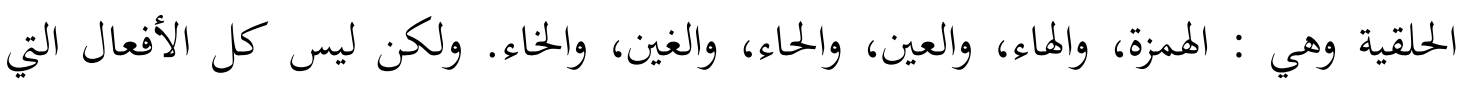

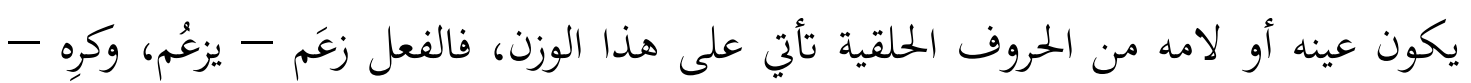

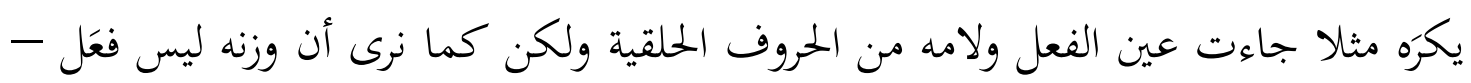
يفعَل بفتح العين في الماضي والمضارع.

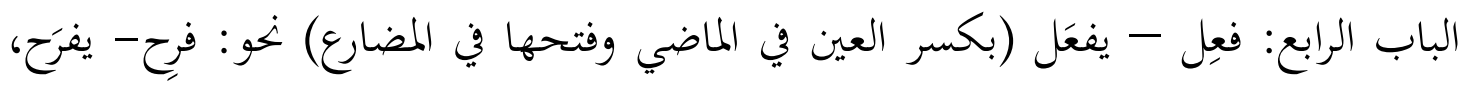

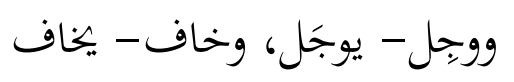

الباب الخامس: فعُل - يفعُل (بضم العين في الماضي والمضارع) نحو: شرُف - يشرُف. فالفعل الماضي الذي عينه مضموم لا يكون مضارعه إلا مضموم العين أيضا.

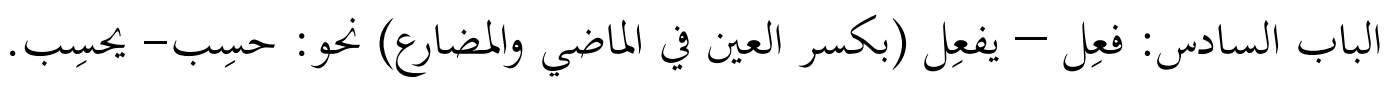

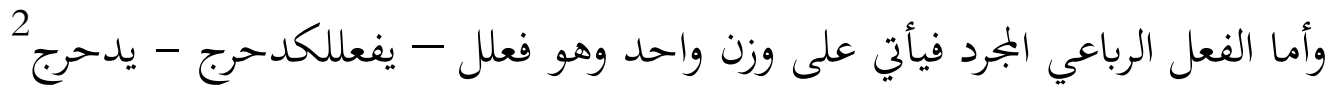

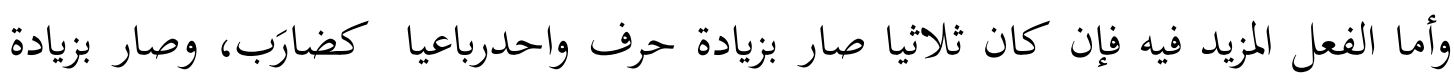

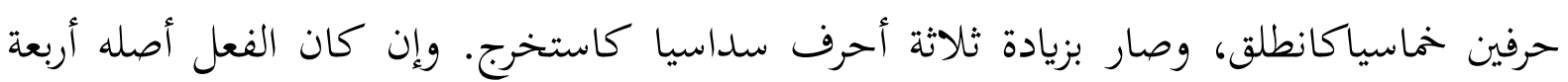
أحرف صار بالزيادة على خمسة كتدحرج، أو على ستة كاحرنجم 3 فالزيادة في الفعل وخاصة الثلاثي منه قد تكون بحرف واحد، وهو على ثلى ثلاثة أوزان منها:

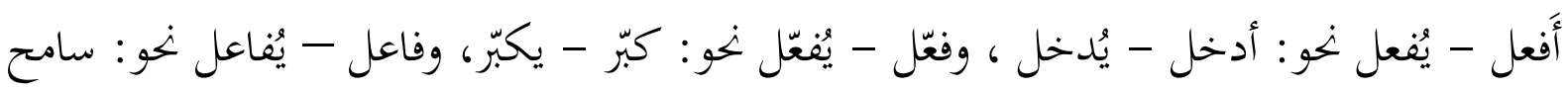

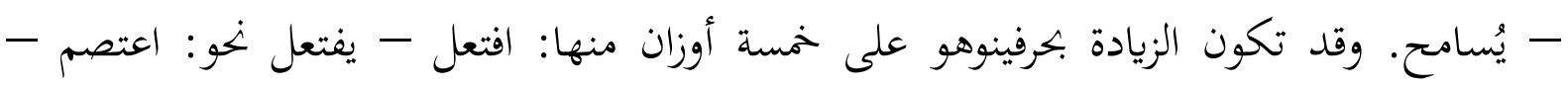
يعتصم، وانفعل - ينفعل نحو: انكسر - ينكسر، وتفاعل - يتفاعل نحو: تعاون - يتعاون، وتفعّل

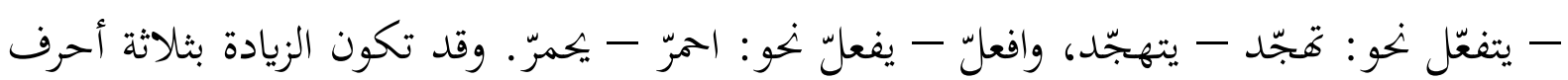




$$
\begin{aligned}
& \text { منها: استفعل - يستفعل نحو: استغفر - يستغفر، وافعوعل - يفعوعل نحو: اعشوشب - } \\
& \text { يعشوشب، وافعالّ - يفعالّ نحو: احمارّ - يحمارّ، وافعوّل - يفعوّل نحو : اعلوّط - يعلوّط. } \\
& \text { معاني صيغ الزوائد }
\end{aligned}
$$

قلنا إن زيادة الحرف في الكلمة - ومنها الفعل - يؤدي غالبا إلى تغير دلالتها، وهنا سنعرض أوزان الأفعال المزيدة مع شرح بعض معانيها الجديدة بعد دخول حرف زائد أو أكثر عليها. وإليكم

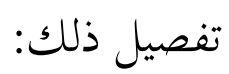

\section{الأفعال المزيدة بحرف واحد$$
\text { الأول: أفعل }
$$

ومن الفعل الثلاثي المزيد صيغة "أفعل"، وهو (للتعدية) أي جعل الفعل اللازم الذي لا يحتاج

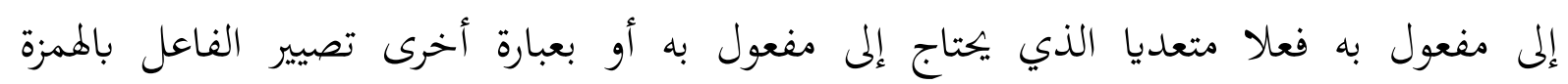

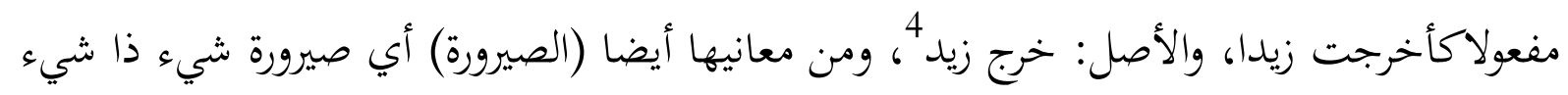

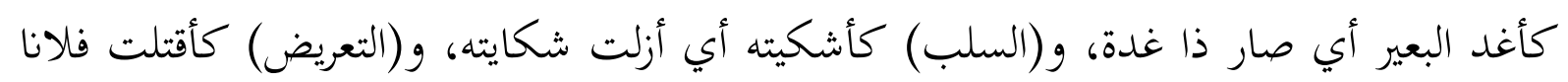
إذا عرضته للقتل، وأبعت الشيء إذا عرضته للبيع، و(وجود الشيء على صفته) كأحمدت فلانا،

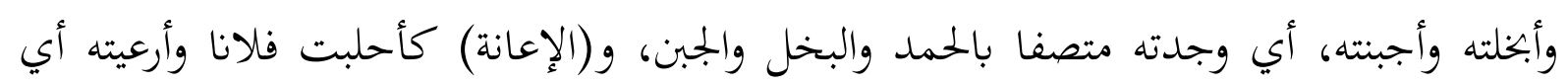

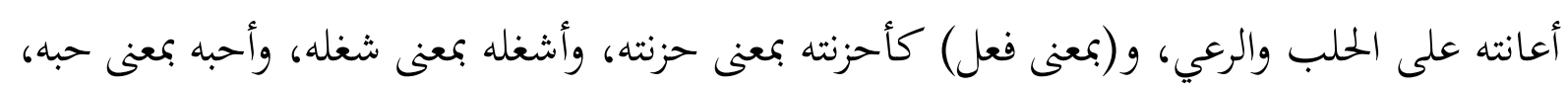

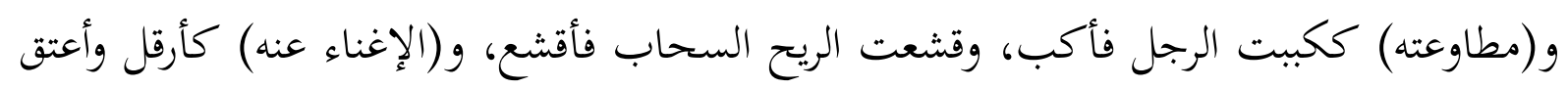

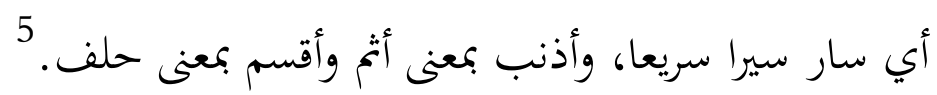
ومن معاني هذه الصيغة أيضا (الدخول في الشيء) مكانا كان أو زمانا، كأشأمأي دخل في في وأئي

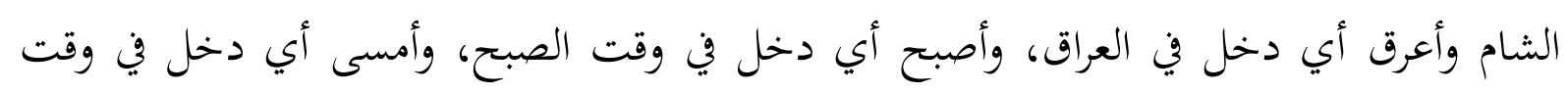

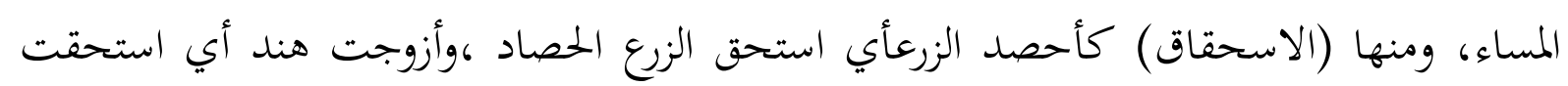
هند الزواج، ومنها (التمكين) كأحفرته النهر أي مكنته من حفره، و(أن يكون مطاوعا لفعّل بالتشديد) والمطاوعة ضد التعدية نحو: فطرّته فأفطر وبشّرته فأبشر. 6

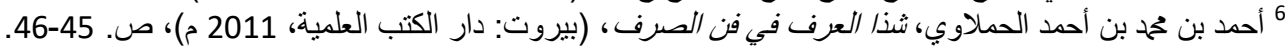


وهذه الصيغة قد تكون (للتعدية) أيضاكأدبت الصبي، و(التكثير) كفّّحت الأبواب وذبّت

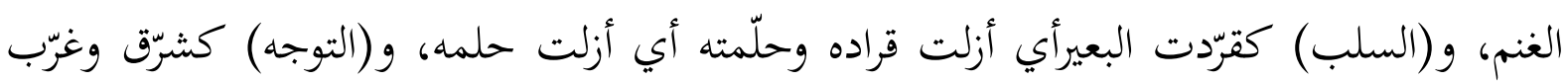
وغوّر وكوّف وبصّر أي توجه نحو الشرق والغرب والغور والكوفة والبصرة، و و(اختصار الحكاية)

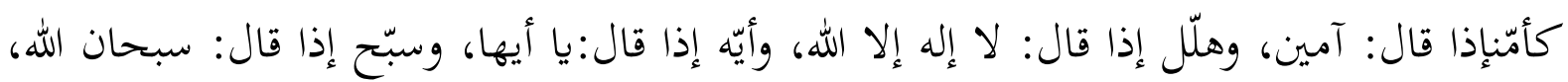
وسوّف إذا قال: سوف، و(بمعنى فعل) بتخفيف العين كقدّر بمعنى قدر، وبشّر وميّز بمعنى بشر إِّر

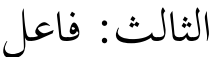

وصيغة "فاعل"قد جاءت للدلالة على اشتراك طريف المفاعلة في معنى الفاعلية والمفعولية، كضارب زيد عمرا، فزيد هنا فاعل ومفعول في نفس الوقت، وكذلك عمرو . وقد تأتي هذه الصيغة لموافقة (أفعل) أي معناه مثل معناه في أفعل، سواء كان في المتعدي كباعدات هنديد الشيء وأبعدته، أو في اللازم: شارفت على البلد وأشرفت عليه.

ولموافقة (فعّل) كضاعفت الشيء وضعّقته، ولإغناء عن (أفعل) كواريت الشيء أي أخفيته،

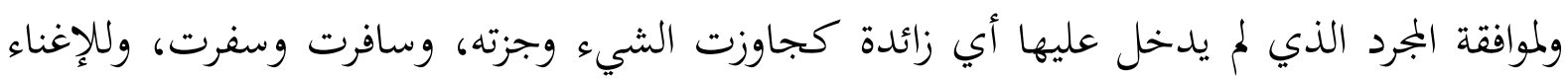
عنهكقايست.

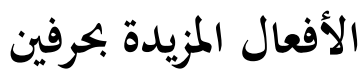

الأول: تفاعل

جاءت صيغة "تفاعل" (للمشاركة) بين الشيئين فأكثر، فكل واحد فاعل في اللفظ ومفعول في المعنى، كتضارب زيد وعمرو، و (التجهيل) وهو أن يدعي الفاعل حصول الفعل دون الحقيقة

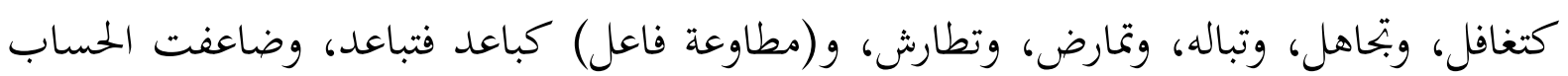

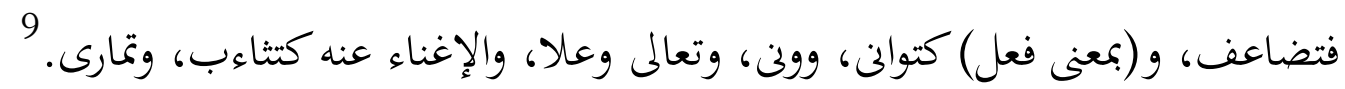
الثاني: تفعّل 
و "تفعّل" لها عدة معانمنها (لمطاوعة فِّل) ككسّرته فتكسّر، وعلّمته فتعلّم، و(التكلف) وهو

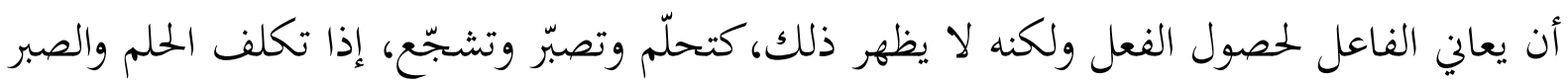

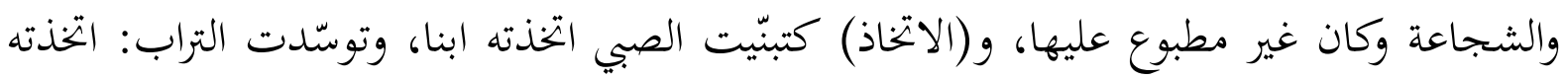

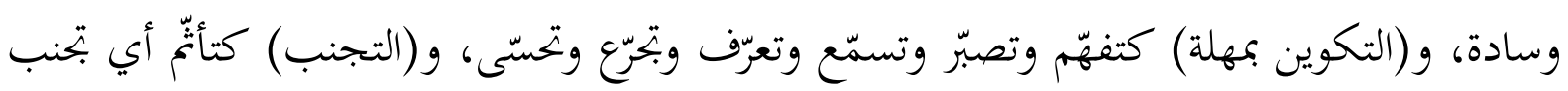

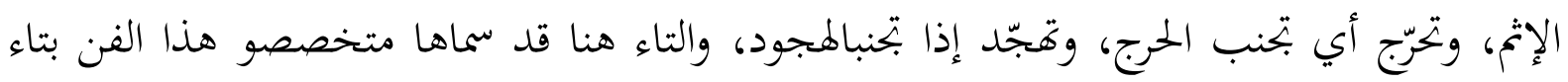

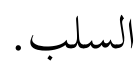

ومعنى آخر الذي تحمله هذه الصيغة هو (الصيرورة) كتأيمّت المرأة وتحجّر الطين وبجبّن اللبن، أي صارت المرأة أيما وصار الطين حجرا وصار اللبن جبنا. و(بمعنى استفعل) كتكبّر وتعظّم، و(بمعنى

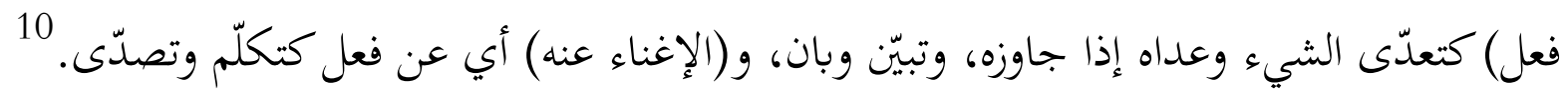
الثالث: افتعل

ومن معاني "افتعل" (الاتخاذ) كاذّبح واطبّخ واشتوى أي التخذ ذبيحة وطبخا وشواء. ومنها

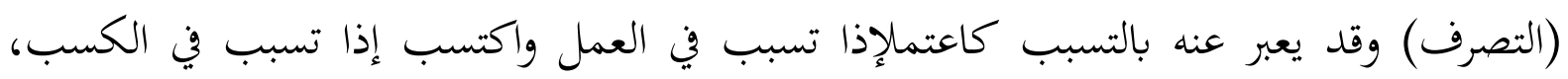

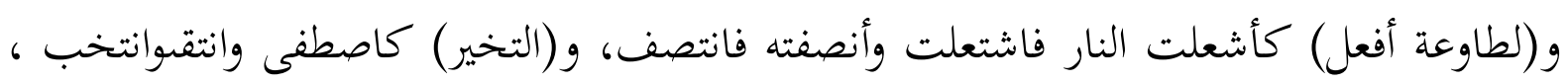

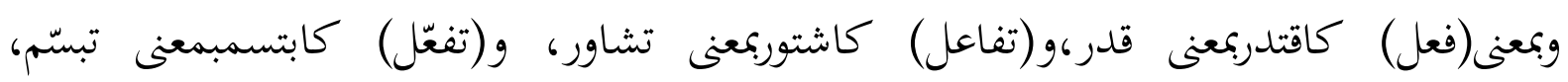

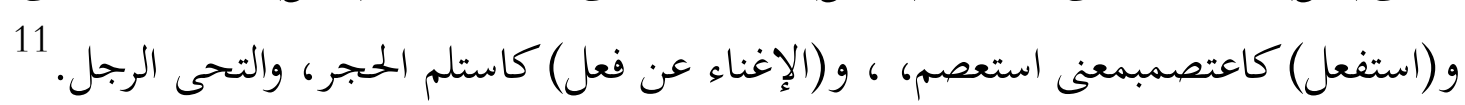

$$
\text { الرابع: انفعل }
$$

جاء هذا الوزن لمعنى واحد فحسب وهو المطاوعة، فهو دائما فعل لازم، ولا يكون إلا في

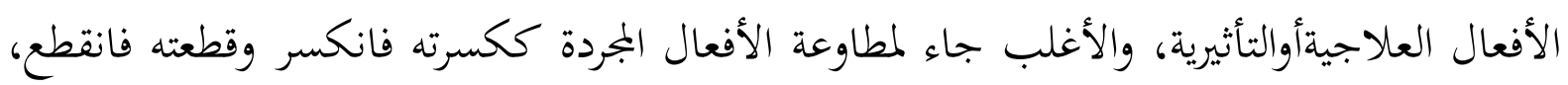

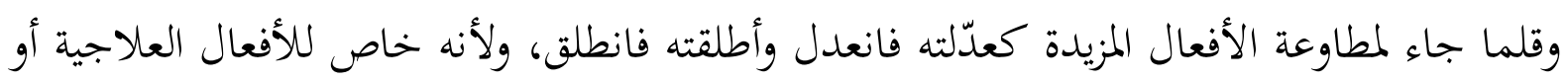

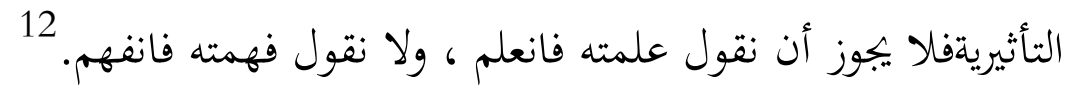
الخامس: افعلّ 


\section{Hasyim Ashari}

صيغة أفعل في سورة البقرة ودلالتها: دراسة وصفية تحليلية

تأتي هذه الصيغة غالبا لتدل على قوة اللونكاحمرّ وابيضّ بمعنى قويت حمرته وبياضه، أو قوةالعيبكاعورّ واعمشّ إذا قويت عوره وعمشه. 13 الأفعال المزيدة بثلاثة أحرف

$$
\text { الأول: استفعل }
$$

ومن الأفعال المزيدة بثلاثة أحرف الذي كثر استعماله هو "استفعل"، وله ستة معان، أحدها:

الطلب، وأكثر الأفعال الذي زيد فيه الألف والسين والتاء يحمل هذا المعنى سواء كان حقيقة أو مجازا، فالحقيقة مثل: استغفرت الله بمعنى طلبت مغفرته، وأما المجاز فمثل: استخرجت الذهب من المعدن، فالطلب هنا بجاز، حيث لا يمكن الطلب الحقيقي. فالممارسة في إخراجه والاجتهاد في الحصول عليه سميت طلبا من باب المجاز.

وثانيها: الصيرورة، وقد تكون حقيقة، نحو: استحجر الطين إذا صار حجرا، واستحصن المهر إذا صار حصانا، وقد تكون ججازا كما في المثل: "إن البغاث بأرضنا يستنسر" أي يصير كالنسر في القوة.

وثالثها: اعتقاد صفة شيء، نهو: استحسنت إذا اعتقدت حسنه، واستصوبته إذا اعتقدت

ورابعها: اختصار حكاية الشيء، فقولنا "استرجع زيد" أكثر اختصارا من قولنا: يقول زيد "إنا لله وإنا إليه راجعون".

وخامسها: القوة، كاستهتر إذا قوي هتره، واستكبر إذا قوي كبره.

وسادسها: المصادفة، كاستكرمت زيدا أي صادفته كريما، أو استبخلته أي صادفته بخيلا. وقد تأتي صيغة "استفعل" بمعنى (أفعل) نحو: استجاب بمعنى أجاب، وقد تأتي لمطاوعته نخو: أحكمته فاستحكم. 14 الثاني: افعنلل

وتأتي صيغة "افعنلل" ليدل على المبالغة وكثرة الفعل كاستحنك. 15 
أما باقي الصيغ فتدل على قوة المعنى زيادة عن أصله، كاحمارّ يدل على قوة اللون أكثر من حمر واحمّ، واعشوشب المكان يدل على زيادة عشبه أكثر من عشب، واخشوشن يدل على قوة الخشونة أكثر من خشن.

وبتحر الإشارة هنا أن بعض الصرفيين قد يعلقون معنى ما بحروف الزيادة، فيقولون مثلا: معنى السين والتاء في (استفعل) هو الطلب، فيجعلون حروف الزيادة لواصق لا زوائد، وفي الوقت نفسه يفردون بابا خاصا يسمونه معاني صيغ الزوائد، وهذا يدل على أفم يعلقون معنى ما بالصيغ لا بالحروف ، وهذا هو المنهج الأمثل لعلاج الموضوع، لأن استخلاص الزائد عن الكلمة إن كان مقبولا في السين والتاء في (استفعل) فإنه غير مقبول في عناصر أخرى كالتكرير التي تصعب نسبة الزيادة

\section{اللمحة عن سورة البقرة}

ثبت عند أهل العلم أن سورة البقرة مدنية، وحكى ابن حجر في فتح الباري الاتفاق على ذلك، وداعم هذا الاتفاقهو أن هذه السورة فيها فرض الصيام، والصيام كتب في السنة الأولى من

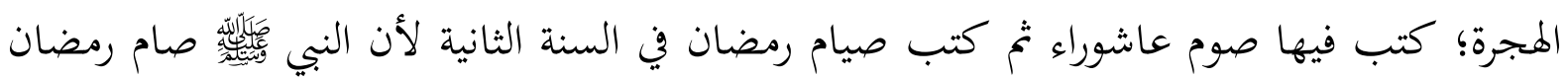

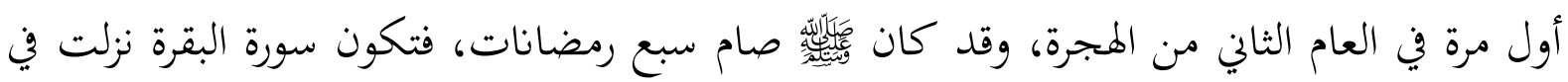
أواخر السنة الأولى من الهجرة أو في الثانية منها. 17 وهي أولى السور المدنية، فعن عكرمة قال:أول سورة نزلت بالمدينة سورة البقرة. وقيل إن سورة المطففين نزلت قبلها بناء على أها مدنية. وسورة البقرة من السور الطوال بل هي أطول سورة في القرآن الكريم على الإطلاق، وعدد آياتَا عند أهل العدد بالمدينة ومكة والشام مائتان وخمس وتمانون آية،وعند أهل العدد بالبصرة مائتان وسبع وثمانون ، وعند أهل العدد بالكوفة مائتان وست وتمانون. 18 ومن فضلها أن فيها أعظم آيات القرآن وهي آية الكرسي التي إذا قرأناها بعد كل صلاة مكتوبة تكون سببا لدخولنا الجنة. والآيتان الآخرتان منها إذا قرأناها كفتانا من كل سوء، وقيل كفتانا 


\section{Hasyim Ashari}

صيغة أفعل في سورة البقرة ودلالتها: دراسة وصفية تحليلية

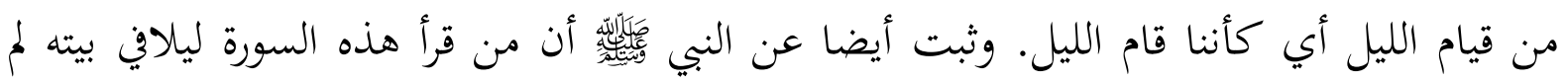

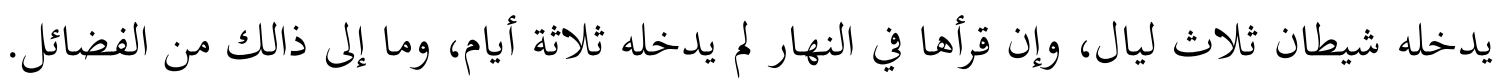

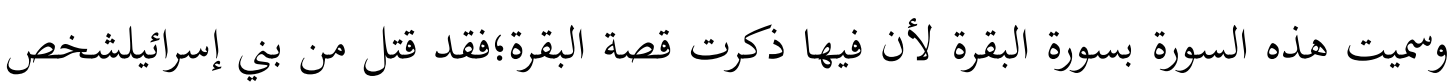
ولم يعرفوا القاتل، فأمرهم الله سبحانه وتعالى بذبح البقرة وضرب الميت بجزء منها، فأحياه الله سبحانه

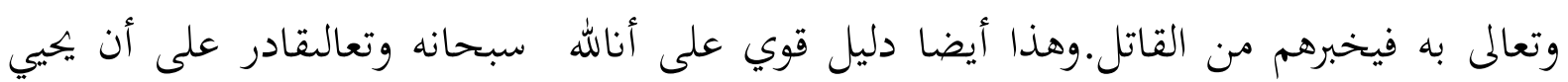
الموتى، ويثبت لنا وجود الحياة بعد موتنا.

\section{دلالات صيغة (أفعل) في سورة البقرة}

وقعت صيغة (أفعَل) كثيرا في سورة البقرة سواء كان ماضيا أو مضارعا، ولكن من معانيها المتعددة وجدنا - من أقوال المفسرين - ثلاثة منها فقط في هذه السورة وهي التعدية والصيرورة وما جاء المهموز كأصله.

\section{ما جاءت للتعدية}

وصيغة (أفعل) في سورة البقرة أكثرها جاءت للتعدية، ومنها:

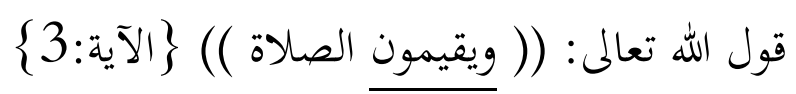

فكلمة يقيم فعل مضارع من أقام وأصله أقوم على وزن أفعل، قلبت الواو ألهاو ألفا لتحركها

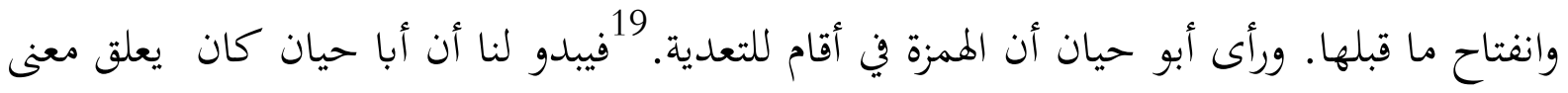
التعدية بحرف زائد وهو الهمزة ولا يعلقه بصيغة أفعل. ورائ

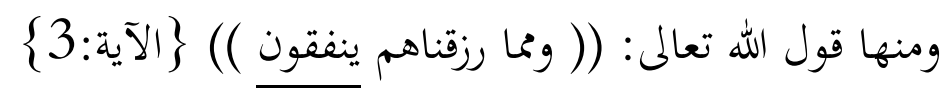

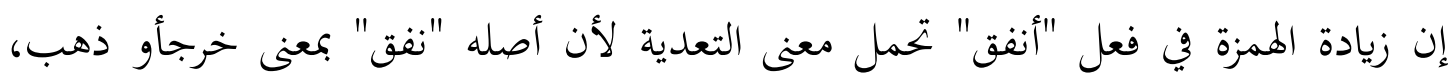

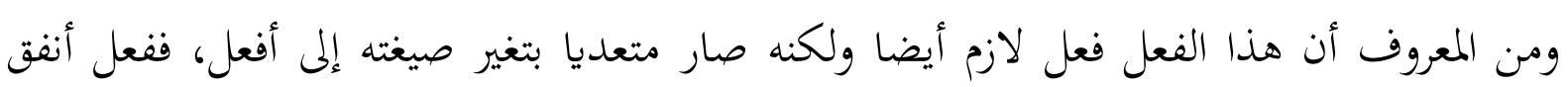
معناه أخرج. ومنها قول الله تعالى: (( والذين يؤمنون بما أنزل إليك وما أنزل من قبلك )) \} الآية:4 
فعل (أُنِل) في هذه الآية الكريمة من الأفعال التي لم يسم فاعلها أو باعتبار آخر الأفعال

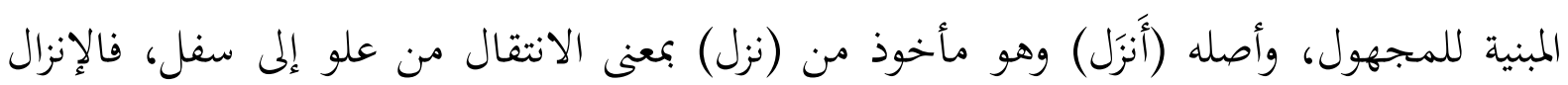

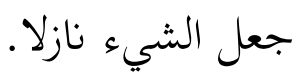

والإنزال هنا يتعدى بأحد أحرف الجر وهو (إلى) لأنه يتضمن معنى الوصف، فالمنزل إليه غاية

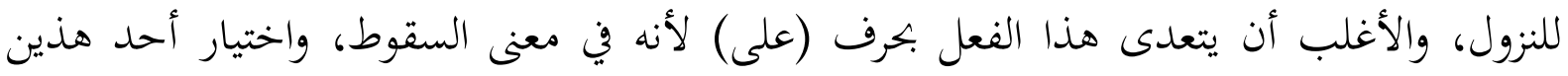
الحرفينمن باب التفنن في الكلام.

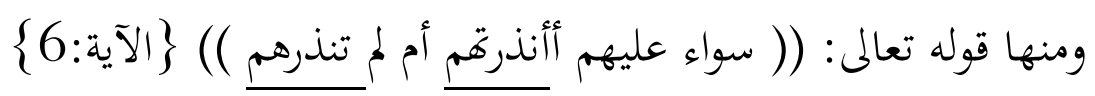

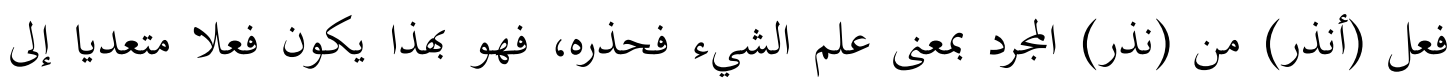

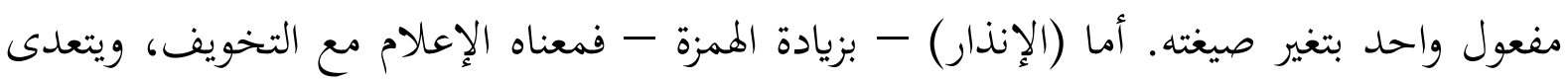

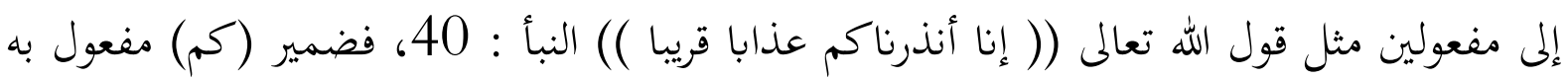
أول، وكلمة (عذابا) مفعول به ثان. 22

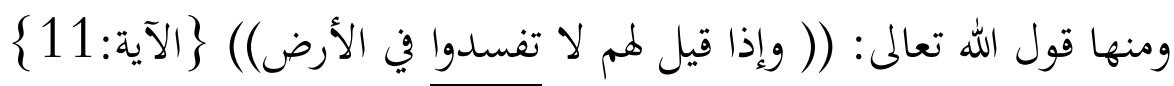

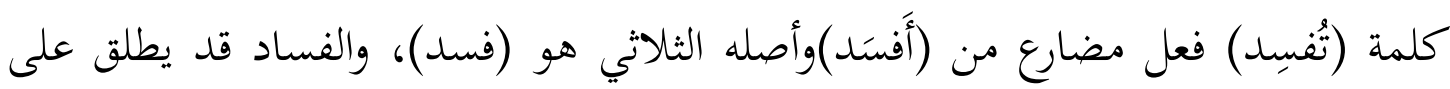

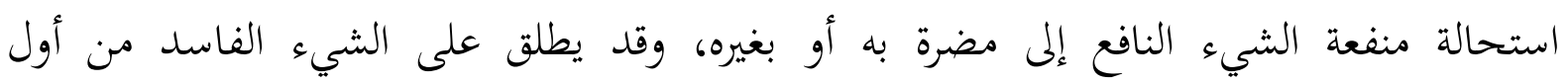

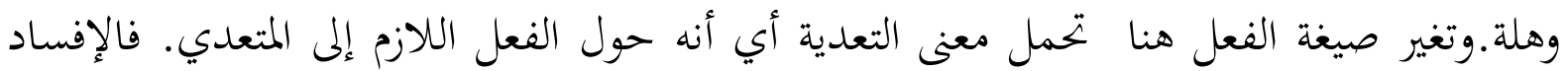

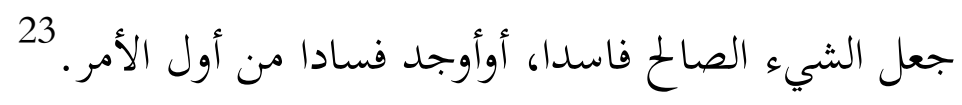

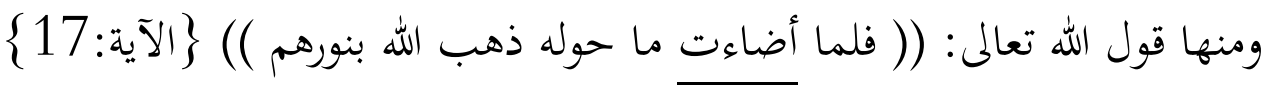

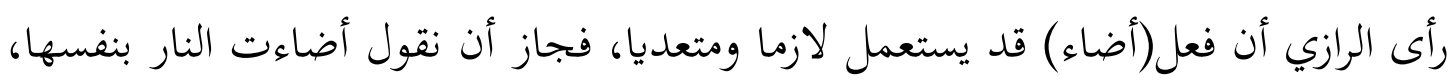

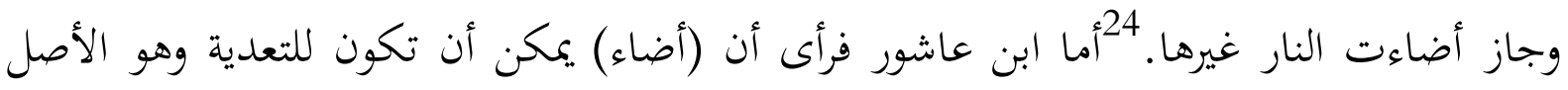

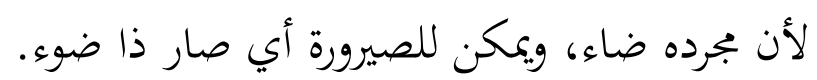


صبغة أفعل في سورة البقرة ودلالتها: دراسة وصفية تحليلية

فاعتبار الهمزة في كلمة (أضاء) للتعدية أو للصيرورة كلاهما صحيح، فإذا افترضنا أها للتعدية فمعناه أن النار أضات الجهات التي حول الذي استوقدها فكان (ما حوله) مفعولا لهذا الفعل، وإذا

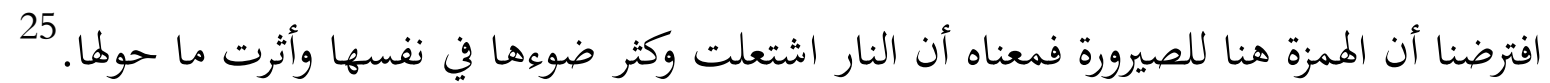

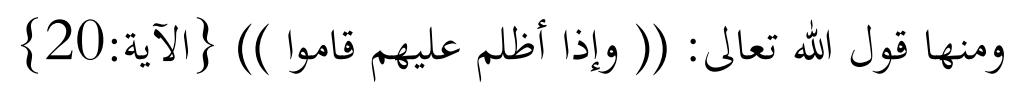
و (أظلم) قد تكون للتعدية وهي قليل، فالأغلب أن يكون هذا الفعل لازما لا يحتاج إلى مفعول به. وإذا قرأنا الجملة التي قبلها وهي ((كلما أضاء لهم مشوا فيه)) وجدنا أن كلمة ولمدي (أضاء) هنا فعل متعد ومفعوله محذوف وتقديره "أضاء لهم البرق الطريق"، فكذلك شأن كلمة (أظلم) أي "إذا واذاء أظلم عليهم البرق الطريق"، ولكن إسناد الإظلام إلى البرق من باب المجاز لأنه ليس سببا في ذلك.

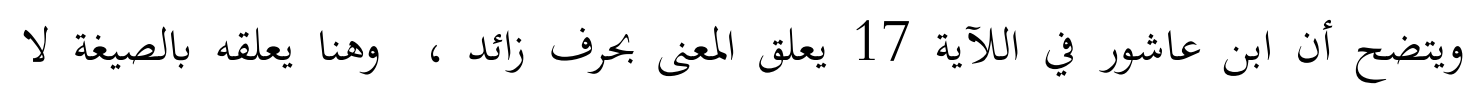
بالحرف.

$$
\text { ومنها قول الله تعالى (( يضل به كثيرا )) \}الآية:26 رفا }
$$

فعل (يضل) بضم الياء فعل مضارع من (أضل) ومجرده (ضل) بمعنى مال عن طريق، وهو

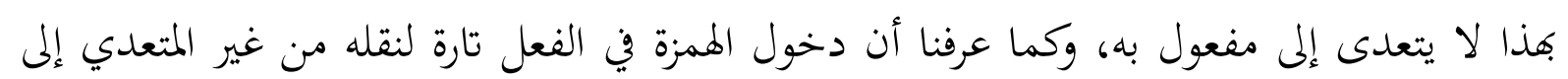

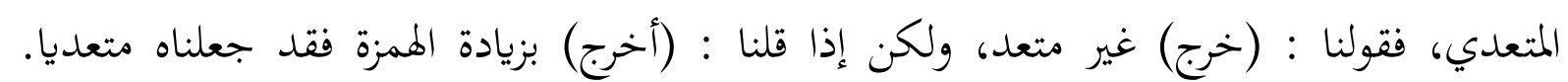

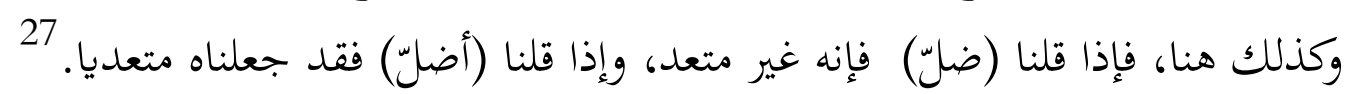

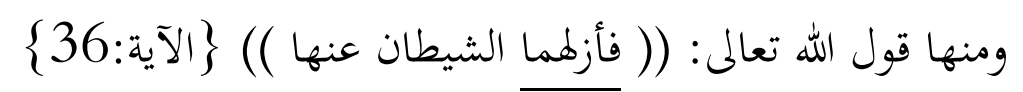

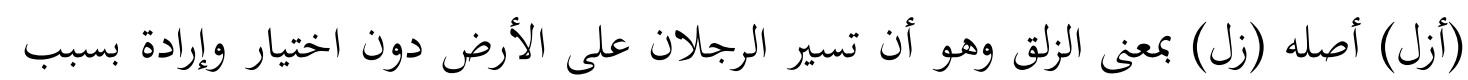

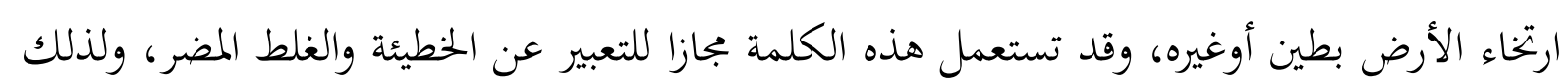

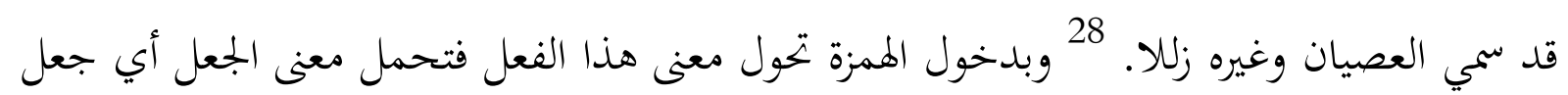
الشيء زالا.

ومنها قول الله تعالى: ((ماننسخ من ءاية أوننسها نأت بخير منها أم مثلها)) \}الآية:106 
ومعنى كلمةالنسخ إبطال الشيء، ورأى القفال أنه للنقل والتحويل، فمثلا نقول: نسخت الريح آثار القوم بمعنى عدمت، ونسخت الشمس الظل بعنى عدم. 29 ولذه الكلمة قراءتان؛ الجممهور قرؤوا: (ننسخ) بفتح النون الأولى وفتح السين وهو أصل مضارع نسخ، وروي أن ابن عامر قرأ هذه الكلمة بضم النون الأولى وكسر السين على أنه مضارع أنسخ، وتغير صيغة الفعل إلى أفعل للتعدية فهو بهذا بمعنى نأمر بنسخ الآية. وأما قوله تعالى (( أو ننسها )) ففيه خلاف أيضا في قراءته، قرأه نافع وابن عامر وعاصم وحمزة والكسائي ويعقوب وأبو جعفر و خلف (ننسها) بضم النون الأول وكسر السين ثم هاء، وقرأه ابن كثير وأبو عمرو (ننسأها)بفتح النون الأولوفتح السين وبعدها همزة ساكنة ثم هاء، فالقراءة بترك الهمزة فهو من النسيان ودخول الهمزة يجعله متعديا، ومفعوله محذوف للعموم أي ننس الناس إياها

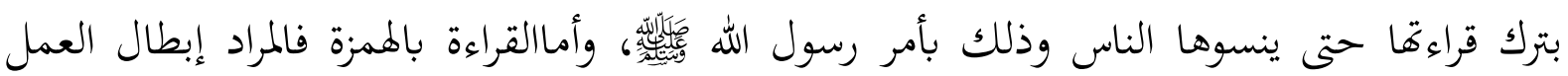
بقراءةا أو بحكمها، لأن معنى (ننسأها) نؤخرها أي نؤخر تلاوتها أو نؤخر العمل بها. 30 ومنها قول الله تعالى: (( وإذ ابتلى إبراهيم ربه بكلمات فأتمهن )) \} الآية:124 كلمة (أتم) أصله الثلاثي (تم) بمعنى كمل وهو ضد النقص، فأتم معناه أكمل، والهمزة هنا للنقل. 31 ويقصد بالنقل نقل الفعل من غير المتعدي إلى المتعدي، ففعل (تحّ) الثلاثي فعل لازم ومعناه

$$
\begin{aligned}
& \text { كمل، وبدخول الهمزة عليها صار (أتم) بمعنى أكمل وهو فعل متعد. } \\
& \text { ومنها قول الله تعالى: (( وأرنا مناسكنا )) }\} \text { (الآية:128 }
\end{aligned}
$$

إن التعدية بزيادة الممزة في أول الفعل لا تقتصر على جعل الفعل اللازم فعلا متعديا، بل قد تكون جعل الفعل المتعدي إلى مفعول واحد فعلا متعديا إلى مفعولين، ففعل "سمع" مثلا فعل متعد الذي يحتاج إلى مفعول واحد فنقول: سمعتُ الخبرَ، وإذا زدنا الهمزة في أوله وصار "أسمع" فكان هذا الفعل يجتاج إلى المفعولين فنقول : أسمعتُ زيداً الخبرَ. وكذالك هنا، فقد رأى ابن عاشور أن (رأى) فعل متعد إلى مفعول واحد، ثم دخل عليه الممزةتعدى إلى مفعولين، أما فعل أرى الذي يتعدى إلى ثلاثة مفاعيل فهو خلاف الأصل وهو 32

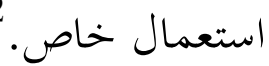




\section{Hasyim Ashari}

صيغة أفعل في سورة البقرة ودلالتها: دراسة وصفية تحلبلية

$$
\text { ومنها قوله تعالى: (( وما كان الله ليضيع إيمانكم )) \} الآية:143 }
$$

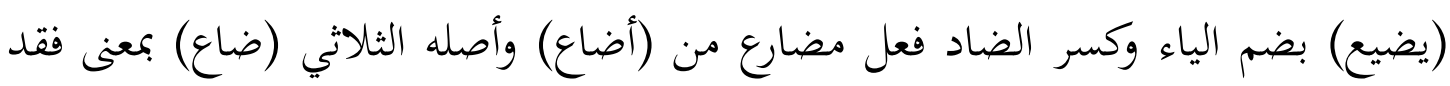

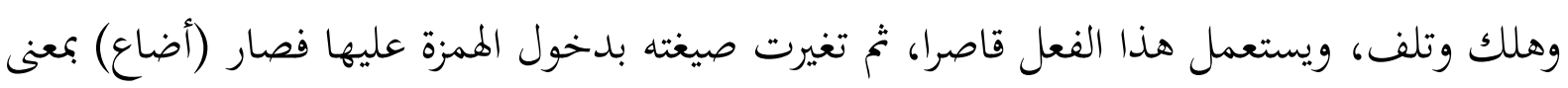

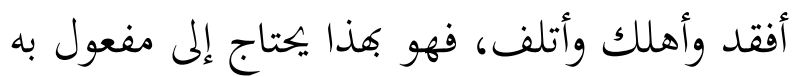
وقرأ الجمهور هذه الكلمة في الآية الكريمة (يضيع) كما هو معروف، وقرأ الضحاك (ليضيّع)

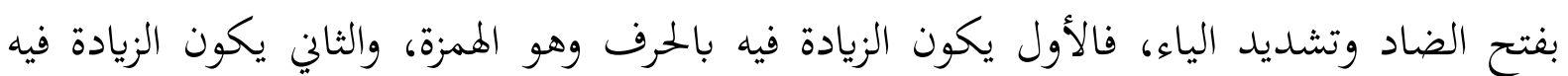
بالتضعيف، وكلاهما يحمل معنى النقل. 33 وغير ذالك كثير مما جاء للتعدية، كقول الله تعالى: (( فأخرج به من الثمرات رزقا لكم )) \} الآية:22\{ وقوله تعالى: (( كيف تكفرون بالله وكنتم أمواتا فأحياكم ثم يميتكم ثم يحييكم)) \}الآية:28\{ وقوله تعالى: (( وأعلم ما تبدون )) \}الآية:33\{ وقوله تعالى: (( وإذ فرقنا بكم البحر فأنجيناكم وأغرقنا آل فرعون )) \}الآية:50\{ وقوله تعالى: (( محا تنبت الأرض))

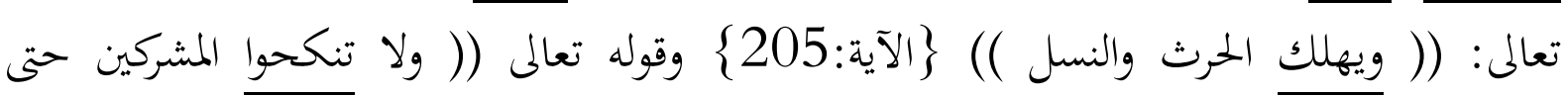

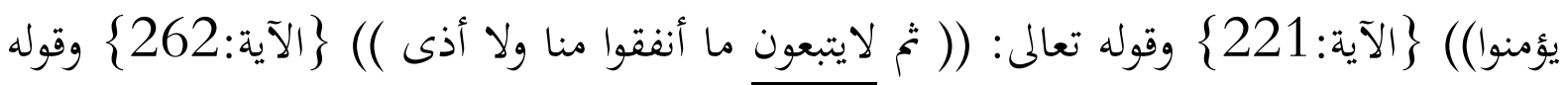

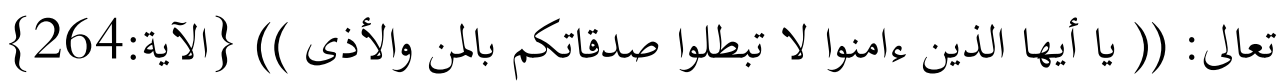

\section{ما جاءت للصيرورة}

ومما جاءت للصيرورة قول الله تعالى: (( الذين يؤمنون بالغيب )) \}الآية:3 فكلمة (يؤمن) فعل مضارع من (آمن) على وزن أفعل والأصل هو الأمن ومعناه الطمأنية،

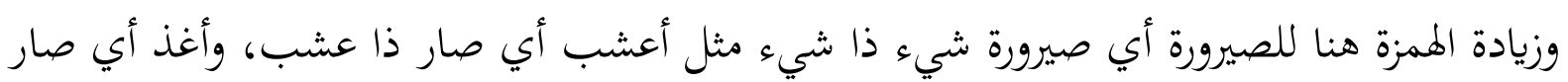
ذا غدة، وقيل أن الهمزة هنا لمطاوعة فعل مثل في (أكب). وقد يتعدى فعل (آمن) بالباء كما في هذه ماء

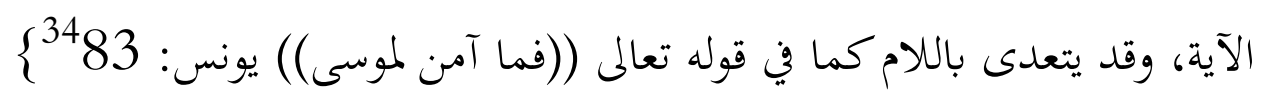

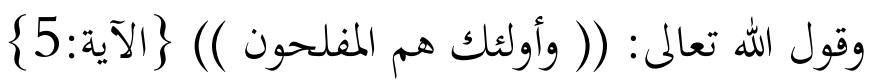


وكلمة (المفلحون) اسم الفاعل من (أفلح) وأصله الثلاثي (فلح) بمعنى الفوز وصلاح الحال، وإذا حملنا هذه الكمة إلى ما يتعلق بأمور الدين فمراده النجاة من العذاب في الآخرة. وزيادة الممزة في

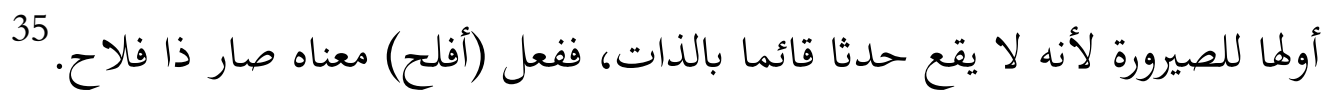
وزعم سيبويه أن الصيرورة والجعل أو التعدية بمعنى واحد، ويبدو ذلك في قوله: "تقول: دخل بله

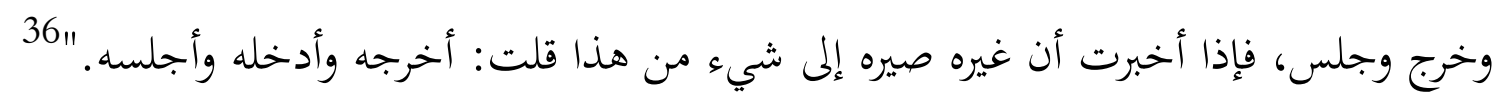

\section{ما جاء المهموز كأصله}

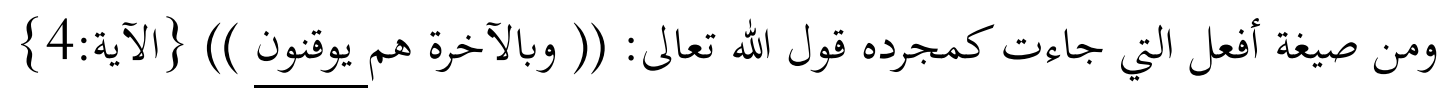
وكلمة (يوقن) فعل مضارع من (أيقن). وأصله يقن بمعنى زوال الشك، واستُعمِل المجرد والمزيد

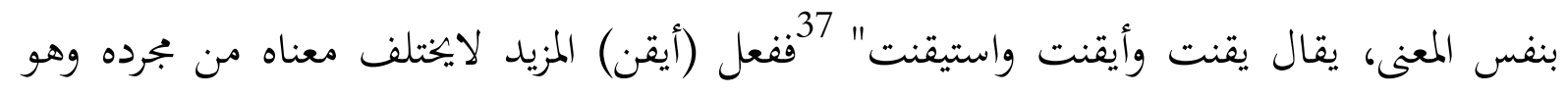
(يقن)

$$
\text { وقول الله تعالى: (( وأوفوا بعهدي )) }\} \text { (الآية:40 }
$$

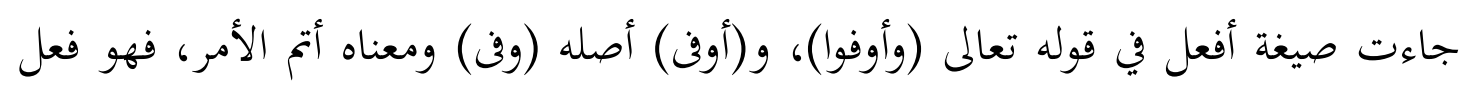

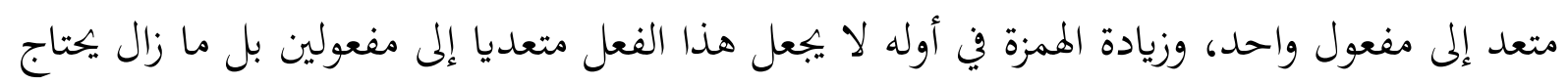

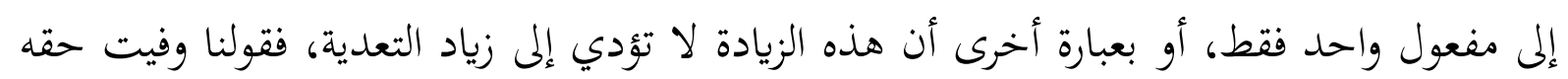
يتساوى بقولنا أوفيت حقه إلا أن المزيد تعينت فيه المبالغة في التوفية. 38 وقول الله تعالى: (( يحبوغم كحب الله ))

قرأ الجمهور (يجبوغم) بضم الياء وكسر الياء، وقرأ أبو رجاء العطاردي (يحِبّوغم) بفتح الياء

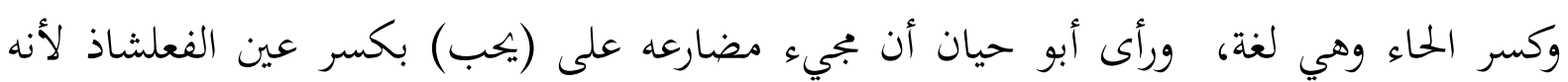

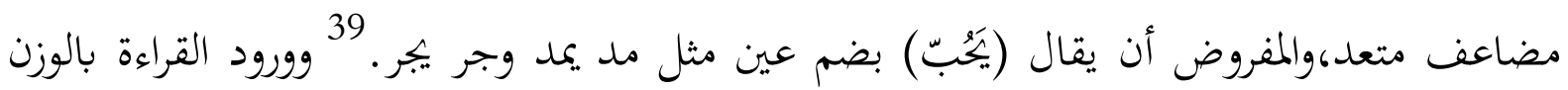

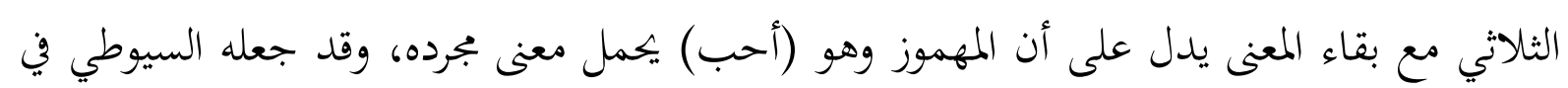
همع الهوامع مثالا مما جاءت فيه صيغة (أفعل) بمعنى (فعل) المجرد.

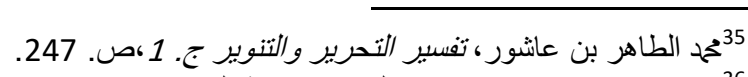

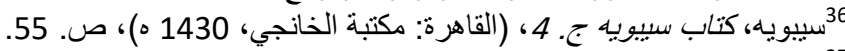

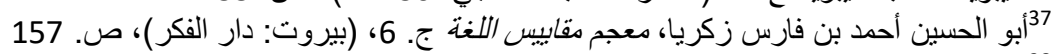

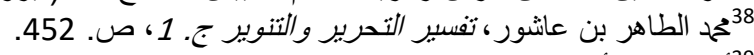

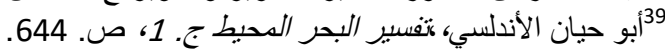




\section{Hasyim Ashari}

صيغة أفعل في سورة البقرة ودلالتها: دراسة وصفية تحليلية

فقد ذهب اللغويون إلى إمكان ورود (أفعل) بمعنى (فعل) اعتمادا على بعض القراءات القرآنية، ومثال ذلك قول الله تعالى في سورة النساء: (( فسوف نصليه نارا )) قرأها الجمهور بضم إنم إنى النون، على حين قرأها الأعمش وحميد بفتحها. ونقل الدكتور شعبان صلاح أنه عندما يتحد (فعل) و (أفعل) في المعنى فإن (فعل) لهجة لأهل الحجاز، وأما (أفعل) فلهجة التميميين.

\section{خاتمة}

بعد أن بحثنا عن وقوع صيغة أفعل في سورة البقرة وما حملت من الدلالات فتوصل الباحث

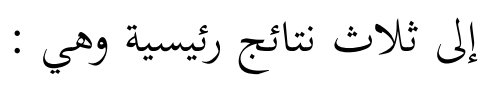

سورة البقرة - وهي أطول السور في القرآن الكريم - اشتملت على كثير من الأفعال بصيغها

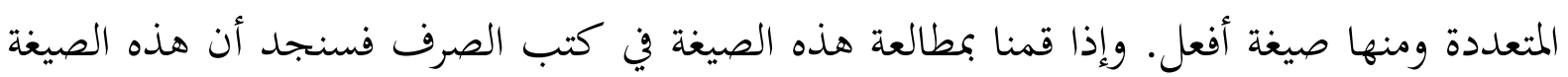
لما معان شتى منها التعدية، والصيرورة، والسلب وما أشبه ذلك. صيغة أفعل في سورة البقرة معظمها جاء للتعدية، وهو جعل الفعل اللازم فعلا متعديا، نحو:

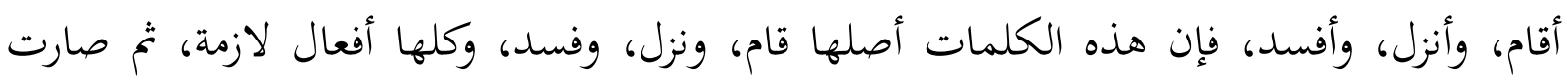

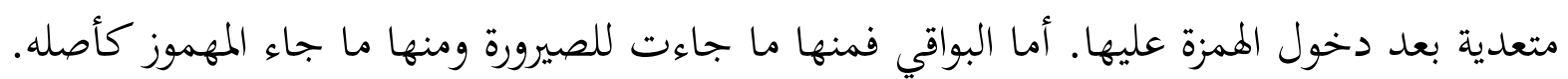
من خلال البحث عن صيغة أفعل في سورة البقرة وجد الباحث أن بعض المفسرين يعلقون

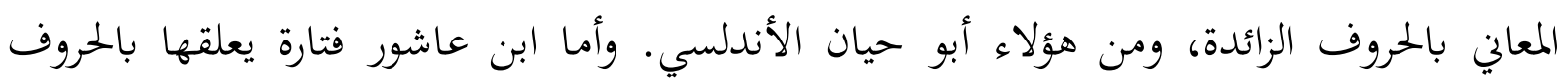
الزائدة، وتارة يعلقها بالصيغة.

وأخيرا، اعترف الباحث بعدم كمال هذه الأطروحة وما زالت تحتاج إلى كثير من الإضافات حتى تكون جدواها أوفن، وتمنى الباحث أن يكون هناك باحث آخر يقوم بإكمالها وخاصة مما يتصل بمعاني صيغة ما، هل هي متعلقة بالحروف الزائدة أم الصيغة.

المصادر والمراجع

القرآن الكريم

ابن جني، أبو الفتح عثمان. الخصائص. بيروت: عالم الكتب. 1427 هـ 30 


\section{ابن فارس، أبو الحسين أحمد.مقاييس اللغة. بيروت: دار الفكر. 1399 هـ} ابن عاشور، مُجمّم الطاهر .تنسير التحرير والتنوير. تونس: الدار التونيسية للنشر، 1984هـ ابن عقيل، بهاء الدين عبد الله.شرح /بن عقيل على ألفية /بن مالك. الطبعة العشرون.القاهرة: دار التراث، 1400 هـ

الأنصاري، ابن هشام.أوضح المسالك. بيروت: المكتبة العصرية، 1435 هـ الأندلسي، أبو حيان يُحَّم بن يوسف.تغسير البحر المحيط. الطبعة الأولى. بيروت: دار الكتب العلمية، 1413 هـ

الأندلسي، أبو حيان تُحَّه بن يوسف:ارتشاف الضرب. الطبعة الأولى. القاهرة: مكتبة الخانجي، 1418

الحملاوي، أحمد بن يُمَّمَ بن أحمد.شذا العرف في فن الصرف. الطبعة السادسة.بيروت: دار الكتب

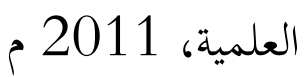

الرازي، فخر الدين.التغسير الكبير (مناتيح الغيب). الطبعة الثانية. بيروت: دار الفكر، 1430هـ السامرائي، تُمَّم فاضل. الصرف العربي أحكام ومعان .الطبعة الأولى. دمشق: دار ابن كثير، 1434 السيوطي،جلال الدين.همع الهوامع في شرح جمع الجوامع.بيروت: مؤسسة الرسالة، 1413هـ حسان، تمام. اللغة العربية معناها ومبناها. القاهرة: عالم الكتب، 2009 م سيبويه، كتاب سيبويه. القاهرة: مكتبة الخانجي، 1430 هـ صلاح، شعبان. مواقف النحاة من القراءات القرآنية حتى فاية القرن الرابع الهجري. القاهرة: دار الغريب، 2005 م 